How to Cite

Chitra, S., \& Aruna, B. (2019). Householder savings \& investment behavior in theni district. International Journal of Humanities,

Literature \& Arts, 2(1), 18-22. https://doi.org/10.31295/ijhla.v2n1.56

\title{
Householder Savings \& Investment Behavior in Theni District
}

\author{
S. Chitra \\ Nadar Saraswathi College of Arts \& Science, India \\ Email: s.citra@gmail.com \\ B. Aruna \\ Nadar Saraswathi College of Arts \& Science, India
}

\begin{abstract}
Investment of hard earned money is a crucial activity of every human being. Investment is one of the foremost concerns of every individual investor as their small savings of today is to meet the expenses of tomorrow. This study deals with investors' preference of Shares, Debentures, Mutual fund, Bank deposits, and Life insurance, etc. Savings of the people are invested in assets depending on their risk and return demands, the safety of money, liquidity, the available avenues for investment, various financial institutions, etc. In a developing country like India, householder savings and investment is the major source of capital for economic activities. Hence, a study of investment behavior of households has to understand the level of knowledge of householders about investment. If the saving is low, then the investment will also be low leading to low capital formation. The present paper explains different reasons for savings, awareness level and the association between demographic factors and awareness level among householders of Theni district.
\end{abstract}

Keywords---crucial, expenses, human, insurance, investment.

\section{Introduction}

Saving is a key principle. People who make a habit of saving regularly, even saving small amounts, are well on their way to success. It's important to open a bank or credit union account so it will be simple and easy for you to save regularly. Then, use your savings to plan for life events and to be ready for unplanned or emergency needs.

The concept of savings plays an important role in economic analysis. Saving is defined as the difference between income and consumption. During the pre-independence period in India. People spent most of their income on consumption and only a small amount of income was left in the form of saving.

Savings generate investment. Investments, in turn, create capital. Capital can be used by the same person, who has accumulated and created it, or it can be lent to others. Normally assets at individuals disposal are suited for a single-time use or application. If householders have an apple in their hands, the minute they start biting it and enjoying it, the apple is no longer there. But wealth or capital represents assets that are put to repeated use (Chitra \& Malarvizhi, 2018); Malarvizhi \& Devi, 2018); Mahalakshmi \& Devi, 2018).

\section{Review of Literature}

Pooranam \& Nandhini (2018); Korry \& Suartini (2019); Wijaya et al., (2018), Finance Indian investors investment characteristics showed that the use of these characteristics for a better understanding of individual investors and their financial product needs. It also shows that investor's future preferences. The study reveals the increasing popularity of equity as an investment option among individual investors.

Arip et al., (2018), on individual investors behavior towards select investments, states that the majority of these investors are giving much importance for the factor "safety". Similarly, investment avenues such as Bank deposits,

ISSN 2632-9441

Received Jan 20, 2019 / Accepted Jun 18, 2019 / Published Jul 05, 2019 
LIC policies, and Bullion has been preferred by the individual investors. Similarly, the majority of the investors are periodically evaluating the performance of their investment avenues.

Suiraoka et al., (2017), on investment behavior of rural investors in their study, states that the investment culture among the people of a country is an essential prerequisite for capital formation and the faster growth of an economy. Investment culture refers to the attitudes, perceptions, and willingness of the individuals and institutions in placing their savings in various financial assets, more popularly known as securities. A study on the investors' perceptions and preferences, thus assumes a greater significance in the formulation of policies for the development and regulation of security markets in general and protection and promotion of small and house-hold investor in particular.

\section{Statement of the Problem}

Saving is a very important component which is responsible for combating or meeting any emergency accrued by the individuals or the households or any corporate agencies. Saving is more of meant for meeting contingencies but sometimes it also acts as a form of investment. But sometimes people are not inclined towards saving and the very delicate reason is lack of awareness. The present study can be a relevant one to know the reason of dissaving and if saving occurs the what are the determinants which are responsible for saving.

\section{Objectives of the Study}

The present study on householder Saving and Investment Behavior in Theni District.

a) To know about the structure of Saving \& Investment pattern in India.

To know about the profile of the respondents.

b) To find out the Savings \& Investment pattern in Householder.

c) To analyze the Householders satisfaction level in Savings \& Investment Behavior.

d) To offer the Summary, Findings \& Suggestions about the study.

\section{Scope of the Study}

This study is an attempt to provide not only a statewide estimate of the extent and patterns of saving and investment in the household sector in rural and urban areas but also the saving and investment profiles of multitudinous categories of households. The findings of this research will also raise a number of an interesting issue for future research. As research reports show that frequency of investment pattern, factors, income level play a more significant role in deciding the pattern of investment. So analyzing the factors that affect the investment pattern of investors and other investment criteria provide valuable insights.

\section{Data Collection}

Primary Data: The study is based on primary data and the necessary data required for the study are collected through questionnaire form 80 respondent.

Secondary Data: Secondary data was collected from various published Journals, Magazines, Report, Websites, and Manuals. Tools of Analysis

a) Simple Percentage

b) Likert's Sealing Technique

c) Ranking Method

\section{Limitations of the Study}

The study has the following limitations:

a) The researcher humbly believes that the present study will be helpful to all the concerned and be an addition in the area of study.

b) The study has been carried out by applying convenience sampling techniques.

c) The study is only applicable to Theni District and not to any other similar areas.

d) The householder savings behavior may differ in future according to the situation. So the same results can't expect in the future. 
Analysis of Data

Simple Percentage

Table 1

Demographic Profile of the Respondent

\begin{tabular}{llll}
\hline Variables & Categories & $\begin{array}{l}\text { No of } \\
\text { Respondents }\end{array}$ & Percentage \\
\hline Gender & Male & 58 & 72.5 \\
Gender & Female & 22 & 27.5 \\
Age of the Respondents & $18-30$ & 27 & 33.75 \\
Age & $31-40$ & 21 & 26.25 \\
& $41-50$ & 32 & 40 \\
Education Qualification of the Respondents & & & 3.75 \\
& Illiterate & 3 & 12.5 \\
Education Qualification & SSLC & 10 & 15 \\
& HSC & 12 & 43.75 \\
Occupation of the Respondents & UG & 35 & 25 \\
Occupation & PG & 20 & 18.75 \\
& & & 27.5 \\
Marital status of the Respondents & Private Employee & 15 & 32.5 \\
Marital Status & Government Employee & 22 & 21.25 \\
& Business & 26 & 60 \\
& Home Maker & 17 & 40 \\
\hline
\end{tabular}

From the above table 1 shows that majority of the respondents(72.5\%) is under Male Category, $(40 \%)$ respondents are under the age group of between 41-50 years; Under Educational qualification of the respondent, most of the respondents are (43.75) having the qualification of UG Degree, $32.5 \%$ of the respondents are doing the Business and $60 \%$ of the respondent are Married.

\section{Satisfaction Factor Analysis}

Likert's Scaling Technique

Most frequently used summated scales in the study of social attitudes follow the pattern devised by Likert. For this reason, they referred to as a Likert type scale. In Likert scale, the respondent is asked to respond to each of the statement in terms of several degrees, usually five degrees (but at times 3 or 7 may also be used) of agreement or disagreement.

As 5 point Likert's scaling technique is under to find out the most influencing factor, points were given below:

Highly Satisfied - 5 Point

Satisfied -4 Point

Neutral - 3 Point

Dissatisfied - 2 Point

Highly Dissatisfied -1 point 
Table 2

Ranking Factor of Satisfaction Level

\begin{tabular}{lllllllll}
\hline S. No & Aspects & HS-5 & S-4 & N-3 & DS-2 & HDS-1 & Total & Rank \\
\hline 1 & Wealth creation & $46(230)$ & $21(84)$ & $11(33)$ & $0(0)$ & $2(2)$ & 349 & I \\
2 & Children Education & $30(150)$ & $34(136)$ & $11(33)$ & $3(6)$ & $2(2)$ & 327 & II \\
3 & Assets dream & $28(140)$ & $24(96)$ & $20(60)$ & $7(14)$ & $1(1)$ & 311 & IV \\
4 & Future uncertain need & $36(180)$ & $20(80)$ & $10(30)$ & $12(24)$ & $2(2)$ & 316 & III \\
5 & Planning for retirement & $25(125)$ & $34(136)$ & $6(18)$ & $7(14)$ & $8(8)$ & 301 & V \\
6 & Others & $31(155)$ & $19(76)$ & $17(51)$ & $5(10)$ & $8(8)$ & 300 & VI \\
\hline
\end{tabular}

Table 2 shows that the householder savings \& investment is highly satisfied with their wealth creation. The second satisfaction level in children education. The third position got the future uncertain need. The fourth position is the assets dream. The fifth position is Planning for retirement and the sixth position is others.

\section{Ranking Method}

Table 3

Main benefit

\begin{tabular}{lll}
\hline Main Benefits & Frequency & Rank \\
\hline Low Income/Under Employment & 30 & I \\
Consumption goods price level is increased & 4 & VI \\
Replacement of debt & 7 & V \\
Unexpected expenditure & 8 & IV \\
Lack of in-depth knowledge & 3 & VII \\
High return (or) profit & 16 & II \\
Income taxes and duties & 12 & III \\
\hline
\end{tabular}

The Table 3 shows that out of seven factors specified while factors affecting the householder savings \& investment, I rank is given Low income/Under-Employment, II rank is given High return (or) profit, III rank is given Income taxes and duties, IV rank is given Unexpected expenditure, V rank is given Replacement of debt, VI rank is given Consumption goods price level is increased, VII rank is given Lack of in-depth knowledge.

\section{Findings}

Findings are the means from interpretation and generalizations which provides suggestions and after the valuable conclusion. In this regard, the researcher consolidates the findings of her research under study.

a) Out of 80 respondents, 58 respondents belongs to the Male.

b) Out of 80 respondents, 32 respondents belong to the age group of 41-50 category.

c) 35 respondents were having the educational qualification of UG Degree.

d) Out of 80 respondents, 30 respondents belong to the Occupation of Business.

e) Out of 80 respondents, 48 respondents were Married.

\section{Suggestion}

On the basis of the above findings the researcher provides the following suggestion from the present study:

a) In our government framed some other saving schemes. It is announced in our government. But the savings amount is based on our income level at a fixed percentage.

b) Today there are so many special Investment schemes in the market which encourage people for saving. In our government make some awareness program is given to the public.

c) To enhance saving habits, the saving mode must attract people by providing many offers and new attractive schemes.

d) One more opportunity is given to the investors for computerized saving the activities.

This activity increased by various promotion activities. 


\section{Conclusion}

Today, the living standard of the people increasing day by day so the householders have started realizing the importance of savings and proper investment of this savings. They avoid spending money on heavy luxurious lifestyle and preferring the normal living standard. It is evident from the study undertaken that most of the people are saving their money for safety, future protects \& fulfill the other goals of life. In our government create a fixed percentage of saving norms announced to the public. These activities are creating the overall the people must follow the fixed savings habit. Because our government frame the norms our citizen are must be followed. This is a bright future to increase our saving \& investment habits of the householder at Theni District.

\section{Reference}

Arip, M., Cembun, -, \& Emilyani, D. (2018). Strategy to improve knowledge, attitude, and skill toward clean and healthy life behaviour. International Journal of Social Sciences and Humanities, 2(3), 125-135. https://doi.org/10.29332/ijssh.v2n3.222

Chitra, S., \& Malarvizhi, M. (2018). A study on Consumer Reaction on Passenger Car Tyre Selection in Theni. International Research Journal of Management, IT and Social Sciences, 5(2), 64-68.

Gupta, K. L. (1970). Personal saving in developing nations: Further evidence. Economic Record, 46(2), 243-249. https://doi.org/10.1111/j.1475-4932.1970.tb02482.x

Gupta, L. C., Gupta, C. P., \& Jain, N. (2001). Indian Households' Investment Preferences: With Special Reference to Debt Market Instruments Based on the 3rd All India Household Investors Survey. Society for Capital Market Research and Development.

Korry, P. D. P., \& Suartini, N. W. (2019). Hedonism and culture toward impact of shopping behavior. International Journal of Social Sciences and Humanities, 3(1), 125-133. https://doi.org/10.29332/ijssh.v3n1.260

Kothari, C. R. (2004). Research methodology: Methods and techniques. New Age International.

Mahalakshmi, G., \& Devi, M. A. (2018). A Study on Customer Satisfaction towards in Health Drinks in Theni District. International Research Journal of Management, IT and Social Sciences, 5(2), 69-74.

Malarvizhi, J., \& Devi, T. C. (2018). A Study on Customer Satisfaction towards Patanjali Products in Theni District. International Research Journal of Management, IT and Social Sciences, 5(2), 75-79.

Pooranam, G., \& Nandhini, K. (2018). A Study on Customer Satisfaction on Commercial Banks in Theni District. International Research Journal of Management, IT and Social Sciences, 5(2), 41-46.

Suiraoka, I. P., Duarsa, D. P. P., Wirawan, I. D. N., \& Bakta, I. M. (2017). Perception of parents, teachers, and nutritionist on childhood obesity and barriers to healthy behavior: a phenomenological study. International Journal of Health Sciences, 1(2), 1-11. https://doi.org/10.21744/ijhs.v1i2.25

Wijaya, M., Giri, M., Wahyuni, N. P., \& Setiawan, K. (2018). Premarital sex behaviors of teenagers: a case in Bali, Indonesia. International Journal of Health Sciences, 2(3), 11-21. https://doi.org/10.29332/ijhs.v2n3.211 